\title{
HIV Attitudes and Practices Among Professors in a Brazilian Dental School
}

\begin{abstract}
Ana V. Pagliari, D.S.; Cléa A.S. Garbin, Ph.D.; Artênio J.I. Garbin, Ph.D.
Abstract: Although there is considerable published research on Acquired Immunodeficiency Syndrome (AIDS), individual biases persist because of lack of information regarding HIV virus transmission. As a result, both infected patients and health care professionals suffer. The objective of this study was to determine if there is prejudice among university professors at the School of Dentistry at Araçatuba's São Paulo State University (FOA-UNESP) concerning HIV-positive patients or HIV-positive health care professionals. Out of the seventy-seven professors who responded to the questionnaire, 62.3 percent (forty-eight) stated that they advise their students not to refuse to treat a patient with HIV. Although 96.2 percent (fifty-two) of the fifty-four professors who treat patients have reported that they treat patients who are HIV-positive, only 65.3 percent of them were aware of infection control precautions, and only 32.7 percent reported that they would treat an HIV-positive patient like any other patient. There is also prejudice regarding HIV-positive professionals because only 48.1 percent (thirty-seven) of the professors responded that they would be willing to be treated by an infected professional. It can be concluded that there is prejudice among some of the FOAUNESP university professors regarding individuals who are HIV-positive.
\end{abstract}

Dr. Pagliari is a Postgraduate Student, Preventive and Social Dentistry Postgraduate Program; Dr. Cléa Garbin is Assistant Professor, Preventive and Social Dentistry Postgraduate Program; and Dr. Artênio Garbin is Assistant Professor, Children and Social Dentistry Department - all at São Paulo State University-UNESP. Direct correspondence and requests for reprints to Dr. Cléa Adas Saliba Garbin, R. José Bonifácio, 1193 Vila Mendonça, Araçatuba-SP, Brazil 16015-150; 18-3636-3249 phone; 18 3636-3332 fax; cgarbin@foa.unesp.br.

Key words: HIV, dentistry, professional ethics, dental education, prejudice, dentist-patient relations

Submitted for publication 3/25/04; accepted 9/9/04

$\mathrm{T}$ he rise of Acquired Immunodeficiency Syndrome (AIDS) epidemics in the 1980s generated discrimination and prejudice towards HIV-infected individuals ${ }^{1}$ and increased the concern among health professionals about the danger of transmission of infectious agents from their patients. ${ }^{2}$ Ignorance of the risk of HIV transmission during dental procedures led many dentists to refuse to treat HIV-positive individuals. In addition, infected dental professionals have sometimes been prevented from practicing dentistry.

There are reports of dentists refusing to treat HIV-positive patients. ${ }^{3-7}$ Gerbert $^{8}$ verified that 74 percent of the dentists interviewed by him in California preferred to direct HIV-positive individuals to specialized centers, despite 70 percent of them believed they had a responsibility to treat these patients. Increased knowledge of issues concerning HIV has led to dental professionals' increased willingness to treat HIV-positive patients. ${ }^{2,8,9}$ The survey carried out by Solomon et al. ${ }^{10}$ in the United States revealed that 62 percent of the undergraduates were willing to treat HIV-positive patients. In Brazil, Garbin et al. ${ }^{9}$ reported that 91 percent of the undergraduates were willing to treat HIV-positive patients, although 43 percent answered that they did not believe that infection control procedures are sufficient to avoid the transmission of the HIV virus. However, if proper barrier precautions are followed, the risk to contract the virus as a result of occupational exposure is very low. ${ }^{2}$ According to the Centers for Disease Control and Prevention (CDC) of the U.S. Public Health Service, ${ }^{11} \mathrm{HIV}$ transmission risk for health care professionals after percutaneous exposure to HIV-contaminated blood was estimated to be between 0.2 and 0.5 percent and following exposure to mucous to be approximately 0.1 percent. In contrast, for $\mathrm{HBV}$ virus, the transmission risk after accidental exposure is between 6 and 30 percent. In 1992, Ciesielski et al. ${ }^{12}$ reported HIV transmission by a Florida dentist to his patients during invasive procedures. It contributed to increased discrimination against HIV-positive health care professionals. 
According to the Brazilian Code of Dentistry Ethics, ${ }^{13}$ Article 6, $\S \mathrm{IV}$, “There is an ethical infringement if a patient is abandoned, except for a justifiable reason." However, specific legislation has not yet been enacted to provide treatment for an HIVpositive patient or for an HIV-positive health care professional's right to keep on practicing dentistry in Brazil. ${ }^{14}$ The U.S. judicial system usually tends to defend the infected patient's right to treatment because it realizes that infection control precautions can protect workers against infection. ${ }^{15,16}$ As for HIVpositive professionals, in 2001, the U.S. Court of Appeals for the $11^{\text {th }}$ Circuit ruled that an infected hygienist represented a "direct threat" to patients and colleagues, individuals who may not be able to protect themselves, ${ }^{15}$ and authorized his employer to prohibit him from providing dental hygiene services. Although other courts of appeals may not follow this decision, it has the potential to affect many health care workers.

Brazil's Ministry of Health ${ }^{17}$ asserts that health care professionals must be able to treat contagious disease-carrying individuals. As for infected dental surgeons, "they can practice dentistry, with no danger to their own health or that of their patients, as long as they employ infection control rules and procedures recommended by the Ministry of Health." The purpose of this research was to evaluate whether there is prejudice among university professors in a dental school regarding treatment of HIV-positive patients and how they felt about HIV-positive health care professionals practicing dentistry.

\section{Methods}

According to Discacciati and Pordeus, ${ }^{2}$ one of the ways to assess a dentist's "willingness index" to treat HIV-positive patients is to obtain pertinent information from the professionals themselves. In this study, dental professors at Araçatuba's São Paulo State University (FOA-UNESP) responded to a written multiple choice survey (Appendix 1) on dental treatment for HIV-positive patients and infected professionals' dental practice.

After the questionnaire was approved by FOAUNESP's Ethics Committee, it was tested with six postgraduate students of the FOA-UNESP's Preventive and Social Dentistry postgraduate program for validation. After the appropriate modifications, the questionnaire was sent to all professors in the dental school. The results were processed and analyzed with the aid of the Epi-Info Program, version 6.04.

\section{Results}

During this study, there were eighty-two professors at Araçatuba's São Paulo State University, School of Dentistry. Seventy-nine professors consented to participate in the study. The responses to the questionnaire from two individuals were considered invalid because they chose more than one alternative on questions 5, 6, and 7 when just one answer was allowed. This resulted in a final total of seventy-seven responses (93.9 percent of the professors).

Twenty-six (33.8 percent) of the professors were female. Six (7.8 percent) had graduated from dental school less than ten years ago, thirty-eight (49.4 percent) between ten and twenty years ago, and thirty-three (42.9 percent) over twenty years ago.

Fifty-four (70.1 percent) of the professors treated patients at the faculty clinic or at private clinics, whereas twenty-three ( 29.9 percent) did not have a clinical practice. In the questionnaire, the latter obviously did not respond to the questions related to clinical practice.

Of the seventy-seven professors interviewed, 62.3 percent (forty-eight) stated that they advise their students not to refuse any type of service for HIVpositive patients and 26 percent (twenty) reported that they advise their students not to refuse emergency service, but to refer patients to another professional in case of nonemergency treatment (Figure 1). Eight (10.4 percent) of the professors were of the opinion that they teach that treatment must be carried out only if the professional feels able to do it and if the working conditions are favorable. No professor stated advising students not to treat HIV-positive patients.

It was not possible to confirm if gender or time of graduation affected the responses in a significant way. It is only possible to report that 57.7 percent of the female professors and 66.7 percent of the male professors said that they teach their students not to refuse to treat HIV-positive patients and that 26.9 percent of the female professionals and 25.5 percent of the male professionals teach their students not to refuse urgent treatment. As for the time of graduation, among professors who graduated ten years ago, between ten and twenty years ago, and more than twenty years ago, 57.1 percent, 64.1 percent, and 64.5 


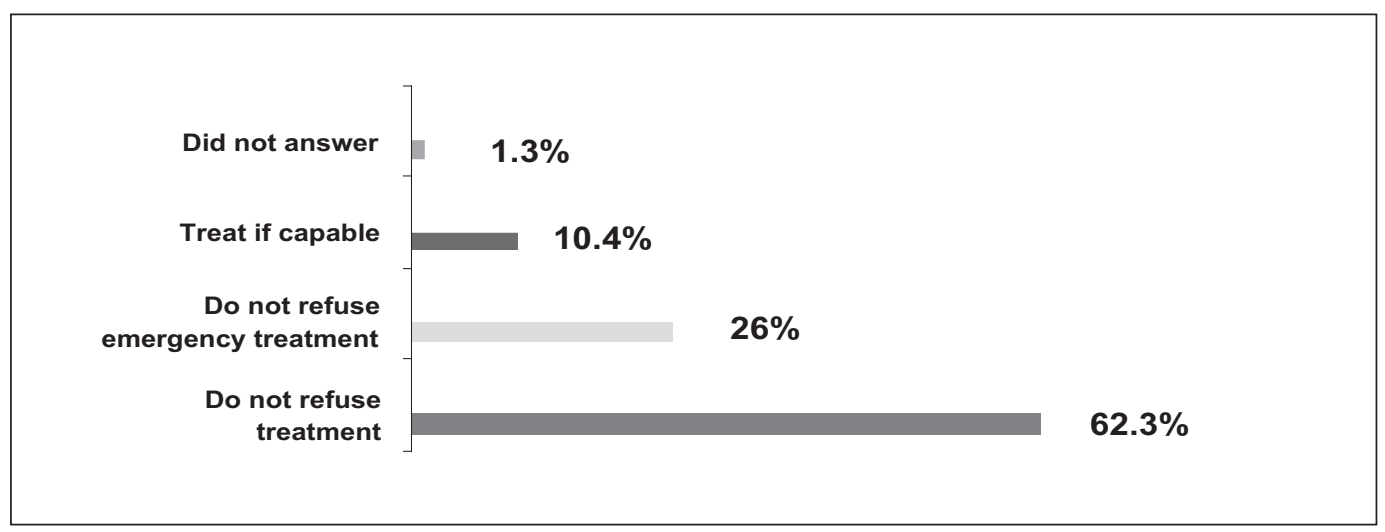

Figure 1. Percentage distribution of the professors' responses related to guidelines given to students

percent respectively answered that they taught their students not to refuse to treat HIV-positive patients; 14.4 percent, 25.6 percent, and 29 percent taught their students not to refuse urgent treatment only.

When asked if they would be willing to be treated by an HIV-positive health care professional, 48.1 percent (thirty-seven) of the seventy-seven professors answered that they would accept any appropriate treatment, and 38.9 percent (thirty) replied that they would accept only non-invasive treatments (Figure 2). Out of the 13 percent (ten) that would not accept any kind of treatment provided by an HIVpositive professional, 50 percent (five) asserted that the fear of being contaminated was the reason for their decision; 30 percent (three) gave reasons such as "precaution," "fear of being one more way to spread the virus," and "possibility of accidents during procedures"-all of which suggest a "fear of contamination." Ten percent (one) pointed to contamination scare and fear of losing clients, and 10 percent (one) alleged contamination scare and fear of prejudice.

Figure 3 shows that, of the fifty-four professors providing clinical service, 54.7 percent (twentynine) reported that they treat HIV-positive patients after taking proper infection control precautions; 32.1 percent (seventeen) stated that they treat HIV-positive patients like any other patient; 9.4 percent (five) said that they attend to these patients on a special schedule; and 3.8 percent (two) answered that they

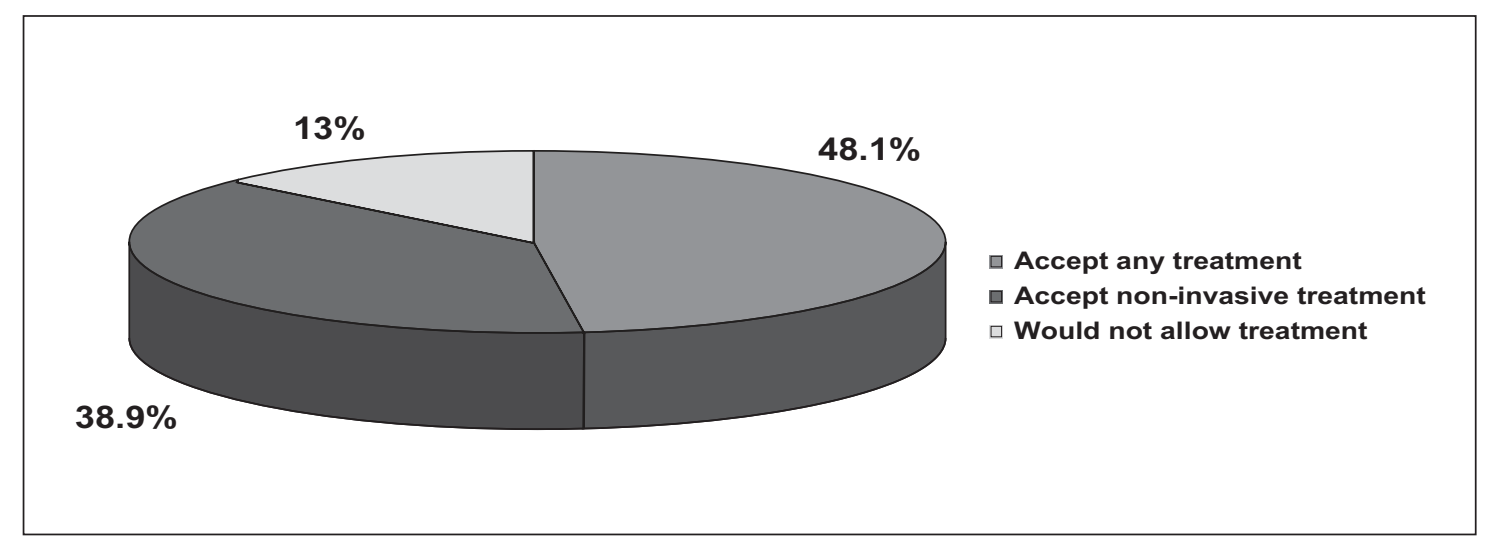

Figure 2. Percentage distribution of professors that would accept to be treated by HIV-positive health care professionals 


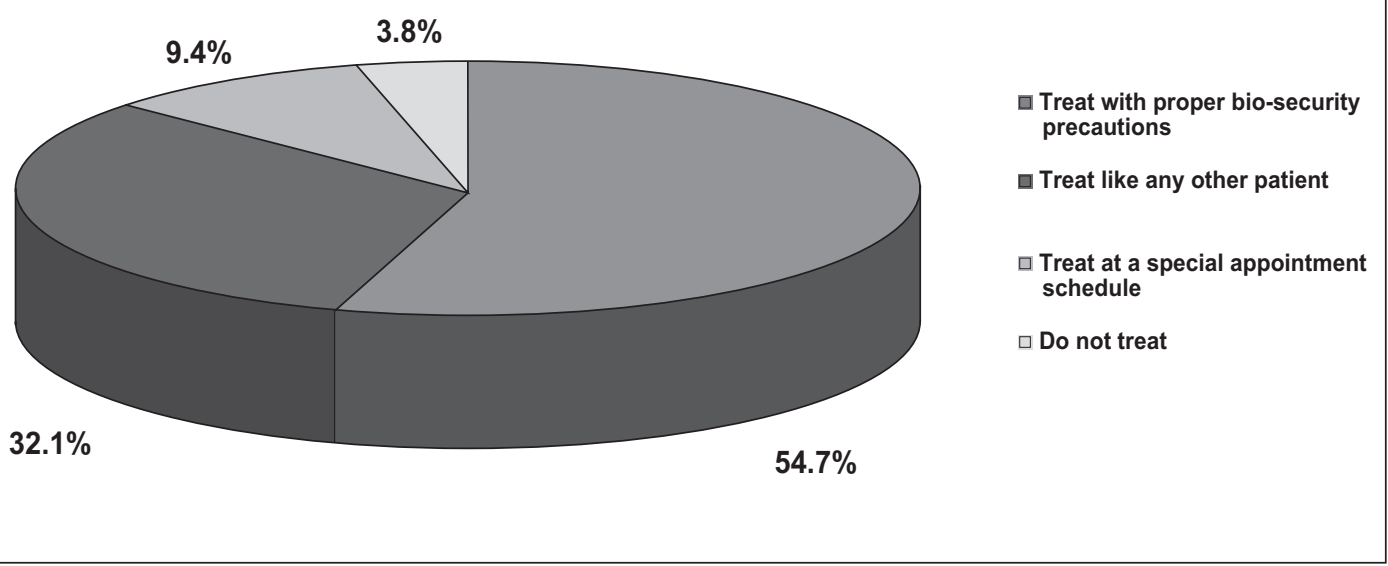

Figure 3. Percentage distribution of the professors' willingness to treat HIV-positive patients

do not treat HIV-positive patients and refer them to an appropriate clinic.

If the professors found out they themselves were infected by the HIV virus, 50.9 percent (twentyseven) of the clinicians said they would normally continue their didactic and clinical activities; 28.3 percent (fifteen) said they would continue with didactic and clinical activities, except for invasive procedures; 18.9 percent (ten) would give up their clinical activities; and 1.9 percent (one) did not know what they would do.

Likewise, if they found out they were HIV-positive, 54.7 percent (twenty-nine) of the clinicians said they would inform their patients about it; 43.4 percent (twenty-three) said they would not inform their patients; and 1.9 percent (one) did not know what they would do (Figure 4). Among those professors who would continue their didactic and clinical activities, 54.8 percent said they would inform their patients about their HIV status, and 45.2 percent would not. Of the professors who answered that they would stop doing only invasive procedures, 60 percent would inform their patients of their HIV status, and 40 percent would not. Among the professors who would not inform others about their HIV status, 69.5 percent (sixteen) would be wor- ried about patients', students', and coworkers' bias, and 30.5 percent (seven) for other reasons such as "there is no need to make the fact known," "irrelevant," and "it does not interfere with treatment."

\section{Discussion}

Although there is considerable research on AIDS, uncertainty towards HIV-positive patients and refusal to treat these patients still persists along with

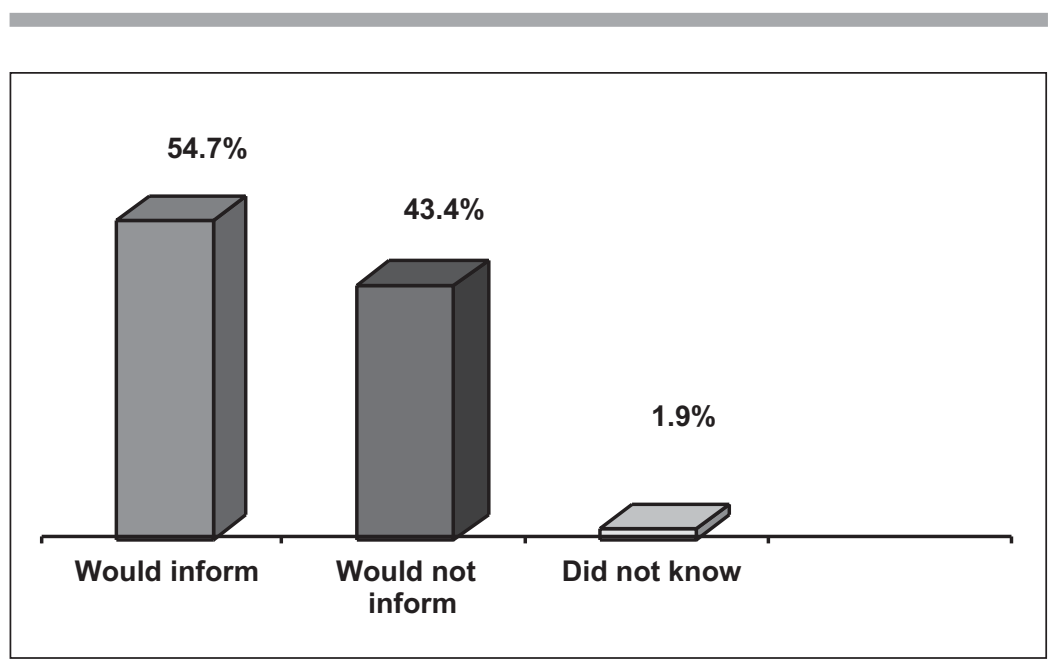

Figure 4. Percentage frequency of the clinicians who would inform their patients in case they contracted HIV 
the fear and possibility that an HIV-positive professional might be prevented from practicing dentistry., 3,6-8 Increased knowledge of issues concerning HIV has led to increased willingness by dentists to treat HIV-positive patients. ${ }^{2,8,9}$ In this regard, the responsibility of health care professionals is high and even higher for university professors in the area of health care because they are responsible for educating their students and other professionals.

When we consider that prejudice is "the opinion or preconceived feeling without sufficient knowledge" and that discrimination means "distinguishing, separating, mistreating someone," 18 it is interesting that, among the fifty-two FOA-UNESP professors who reported treating HIV-positive patients, 55.7 percent responded that they treat their patients after taking appropriate infection control precautions, and 9.6 percent had a special appointment schedule because they needed time to carefully prepare the dental office. Only 32.7 percent of the FOA-UNESP professors reported that they treat HIVpositive patients like any other patient.

Brazil's Ministry of Health asserts that all patients should be treated with the same infection control procedures that should be routinely applied in every dental treatment (sterilized instruments, noncontaminated operative field, professionals wearing gloves, masks, caps, glasses), ${ }^{17,19,20}$ especially because some HIV-positive individuals do not inform their health care professional about their serological condition for fear of being refused treatment. ${ }^{5}$ This refusal is often rationalized by technical arguments such as lack of specialty training or by charging high fees. ${ }^{19}$ Our results show that 10.4 percent of the professors reported that they advise their students to treat HIV-positive patients as long as they feel they are competent to do so, by taking appropriate infection control precautions and making sure that the operatory is adequately prepared for treatment.

According to Smith and Pinheiro, it is not a justifiable reason to refuse to treat an HIV-positive patient because of lack of specialty training or lack of appropriate equipment because it is the professional's responsibility to stay abreast of advances in his or her field in order to treat all patients. ${ }^{21,22}$ However, according to the Brazilian Code of Dentistry Ethics, professionals have the right to refuse to work in a public or private office that is lacking in healthy working conditions. ${ }^{23}$ As dentists have the obligation to provide safe treatment for all patients, including HIV-positive individuals, the decision to treat or not treat a patient whose general status can be fragile depends on good judgment and prudence.
In this study, the professors also exhibited preconceived ideas regarding HIV-positive health care professionals because when asked if they would be willing to be treated by an HIV-positive professional, only 48.7 percent (thirty-seven) of the professors responded that they would accept treatment, whereas 38.9 percent (thirty) responded that they would not be willing to be treated by an HIV-positive professional. After analyzing their responses, it was apparent that all the professors who would not be willing to be treated by an HIV-positive professional were afraid of becoming infected because of "contamination."

Similarly, if the professionals found out they were themselves infected by the virus, 43.4 percent (twenty-three) responded that they would not inform their patients about it. Of these professionals, 69.5 percent (sixteen) said that they would be worried about their patients', students', and coworkers' biases. When it comes to informing others about their serological condition, dental surgeons behave like any other person: they are afraid of prejudice, judgment, and discrimination..$^{20}$ As such, there is no legal obligation for HIV-positive dental health professionals to inform others about their serological status. ${ }^{24}$ Nevertheless, these professionals must strictly employ infection control procedures. ${ }^{17}$

Therefore, although they report that they teach their students not to act in a discriminatory manner towards HIV-positive patients, the professors themselves exhibited prejudice towards infected patients and professionals. Consequently, this topic must be further explored and debated in the academic milieu.

\section{Conclusion}

In conclusion, while a few FOA-UNESP university professors were not willing to treat HIV-positive patients, most of them expressed the need for special infection control precautions, and a few professors asserted that they would treat HIV-positive patients like any other patient. Prejudice towards infected health care professionals was also evident among the professors who responded to the questionnaire because some of them would not be willing to be treated by an HIV-positive professional and several professors said that they would be willing to be treated only if treatment did not involve invasive procedures.

The concern regarding a misinformed society's prejudice appears to be still high among health care professionals because participants in this study said 
they would not be willing to inform their patients about their serological status if they found out they were infected because they were concerned about colleagues', patients', and students' biases. Therefore, it is evident that there is a need for better dissemination of knowledge regarding HIV transmission in the academic milieu as well as in the general population.

\section{Acknowledgments}

The authors would like to thank the professors of the School of Dentistry at Araçatuba's São Paulo State University (FOA-UNESP) who kindly agreed to participate in this survey.

\section{REFERENCES}

1. Gomes MC. Reintegração judicial de trabalhadores soropositivos dispensados do trabalho discriminatoriamente e/ou preconceituosamente (Judicial reintegration of HIV-positive workers that were distinguished released from work). Boletim Direitos Humanos 1999;2. At: www.aids.gov.br/rede.htm. Accessed: July 1, 2003.

2. Discacciati JAC, Pordeus IA. Você está disposto a tratar pacientes com AIDS? (Are you willing to treat HIV-positive patients?). Rev Cons Reg Odontol Minas Gerais 1997;3(1):31-6.

3. Gerbert B, Maguire B, Badner V, Greenspan D, Greenspan J, Barnes D, et al. Changing dentists' knowledge, attitudes, and behaviors relating to AIDS: a controlled educational intervention. J Am Dent Assoc 1988;116(7): 851-4.

4. Gerbert B, Sumser J, Chamaberlin K, Maguire BT, Greenblatt RM, Macmaster JR. Dental care experience of HIV-positive patients. J Am Dent Assoc 1989;119:601-3.

5. Lopes VS, Pordeus IA, Paixão HH, Discaciatti JAC. Indivíduos HIV positivos: revelação de soropositividade e negação de atendimento odontológico (HIV-positive people: soropositive revelation and dental treatment denial). Pesqui Odontol Bras 1988;15:182.

6. Ramos DLP, Maruyana NT. A discriminação no atendimento odontológico a pacientes HIV+ (Discrimination in HIV-carriers' dental treatment). O mundo da Saúde 1996;2:20.

7. Disccacciati JAC, Villaça EL. Atendimento odontológico ao portador do HIV: medo, preconceito e ética profissional (HIV-carriers' dental treatment: fear, prejudice, and professional ethics). Rev Panam Salud Publica 2001;9(4): 234-9.

8. Gerbert B. AIDS and infection control in dental practice: dentists' attitudes, knowledge and behavior. J Am Dent Assoc 1987;114(3):311-4.

9. Garbin CAS, Garbin AJI, Barbosa ALP, Mariano RQ. HIV: você aceitaria ser tratado por um profissional de saúde portador deste vírus? (HIV: would you agree to be treated by an HIV-carrier health care worker?). Odontologia e sociedade 2001;3(1/2):60-4.
10. Solomon ES, Gray CF, Gerbert B. Issues in the dental care management of patients with bloodborne infectious diseases: an opinion survey of dental school seniors. J Dent Educ 1991;55(9):594-8.

11. Centers for Disease Control and Prevention (CDC). Updated USPHS guidelines for managing occupational exposure to $\mathrm{HBV}, \mathrm{HCV}$ and $\mathrm{HIV}$ and considerations for Dentistry. J Am Dent Assoc 2002;133(12):1627-9.

12. Ciesielski C, Witte J, Luo CC, Bell K, Curran J. Transmission of human immunodeficiency virus in a dental practice. Ann Intern Med 1992;116(10):798-805.

13. Conselho Federal de Odontologia. Código de Ética Odontológica (Dentistry ethical code). Rio de Janeiro: Conselho Federal de Odontologia, 2002.

14. Sposto MR, Santos SG, Domaneschi C, Navarro CM, Onofre MA. Avaliação do conhecimento sobre a infecção HIV de estudantes de odontologia antes e após palestra informativa (Knowledge valuation of dental students about HIV infection before and after an informative lecture). J Appl Oral Sci 2003;11(2):125-32.

15. Lewis BE, Vernaglia LW. The application of disabilities law to HIV-positive professonals in the dental practice setting. J Mass Dent Soc 2002;51(3):8-11.

16. Sfikas PM. HIV and discrimination: a review of the Waddel case and its implications for health care professionals. J Am Dent Assoc 2002;133:372-4.

17. Ministério da Saúde. Secretaria de Políticas de Saúde. Coordenação Nacional de DST/AIDS. Área Técnica de Saúde Bucal. Controle de Infecçães e a prática odontológica em tempos de AIDS (National coordination of DST/AIDS: infection control and dental practice in AIDS' epoch). Brasília: MS, 2000.

18. Houaiss A, Villar MS, Franco FMM. Dicionário da l'ngua portuguesa (Portuguese dictionary). Rio de Janeiro: Objetiva, 2001.

19. Ramos DLP. A Odontologia e a AIDS: algumas questões éticas (Dentistry and AIDS: some ethical issues). Rev Cons Fed Odontol 1998;6(23):35-8.

20. Rezende LR, Ramos DLP. Cirurgião-dentista, sorologia positiva para HIV: as opiniões de um segmento da categoria odontologia sobre a questão (HIV-positive dentists: the opinions of a group about the issue). Anais do XVI Congresso Brasileiro de Medicina Legal, V Congresso Brasileiro de Odontologia Legal. Recife: Instituto Brasileiro de Ensino e Pesquisa em Medicina e Odontologia Legal, 2000.

21. Smith CJ. HIV infection and AIDS: educational and ethical aspects in relation to dentistry. Br Dent J 1993; 175(2):75-7.

22. Pinheiro ALB. Onde está a nossa responsabilidade? É ético recusar atendimento ao paciente soropositivo para o HIV ou com AIDS? (Where is the responsibility? Is it ethical to refuse treatment to a HIV-positive carrier or with AIDS?). Rev Assoc Paul Cir Dent 1998;1(6):14-9.

23. Ramos DLP, Silva M. Aspectos éticos do atendimento odontológico a pacientes HIV+ (Ethical issues of HIVcarriers' dental treatment). Rev Assoc Paul Cir Dent 1994;48(3):1341-5.

24. Chikte UME, Naidoo S. Ethical and legal issues around HIV/AIDS in dentistry in South Africa. S Afr Dent J 2000;55(12):701-5. 


\title{
APPENDIX 1
}

\section{UNESP, São Paulo State University, Dentistry School, Campus at Araçatuba}

Preventive and Social Dentistry Postgraduate Program

Area of Bioethics

Dear Professor, please answer the following questions:

1. Gender: A ( ) male B ( ) female

2. Time of graduation: A ( ) less than 10 years ago.

B ( ) between 10 and 20 years ago.

C ( ) more than 20 years ago.

3. Graduation: ( ) Dentistry ( ) others:

Answer the questions below even if you are not graduated from Dentistry School:

\author{
4. What is your professional occupation? (more than one answer possible) \\ a) ( ) professor of theoretical subject matters \\ b) ( ) professor in practical/laboratory classes \\ c) ( ) professor in practical/clinical classes \\ d) ( ) dental clinic/office (private)
}

5. What kind of orientation do you give your students related to treating HIV-positive patients?

a) ( ) They must not refuse to provide any kind of treatment to HIV-positive patients.

b) ( ) They must not refuse to provide urgent treatment to HIV-positive patients, but they can direct them to another clinic if treatment is not urgent.

c) ( ) They can refuse to provide any kind of treatment to HIV-positive patients.

d) ( ) Another orientation:

6. Would you accept to receive health treatment (dental, medical, nursing care) if you knew that the professional responsible for your treatment is infected by the HIV virus?
a) ( ) Yes, I would accept any kind of treatment.
b) ( ) Yes, I would, except for invasive treatment.
c) ( ) Yes, I would, but only for an appointment.
d) ( ) No.

In case of negative answer, why? (more than one answer possible)
a) ( ) fear of contamination
b) ( ) fear of losing your own clients, in case they get to know about it.
c) ( ) fear of prejudice from workmates, students, or family members in case they get to know about the situation.
d) ( ) another reason:

7. Would you allow any family member (e.g., child, father) to be treated by an HIV-positive professional?
a) ( ) Yes, for any kind of treatment.
b) ( ) Yes, I would, but except for invasive procedure.
c) ( ) Yes, I would, but just in case of appointment.
d) ( ) No, I would not. 


\section{APPENDIX 1-continued}

UNESP, São Paulo State University, Dentistry School, Campus at Araçatuba

\section{Answer the questions below in case you carry out clinical activities, having direct contact with patients,} at the dental office and/or dentistry school:

8. What is your criterion to treat HIV-positive patients?

a) ( ) I treat them by taking proper infection control steps.

b) ( ) I treat them like any other patient.

c) ( ) I do not treat them, I prefer to direct them to a specialized service. Why?

d) ( ) I treat them with a special appointment schedule. Why?

9. If you found out you were infected by HIV, would you keep on carrying out your dental activities?

a) ( ) Yes, I would keep on carrying out my didactic and clinical activities as usual.

b) ( ) Yes, I would keep on carrying out my didactic and clinical activities, except for procedures with bleeding.

c) ( ) I would keep on carrying out my didactic activities, but I would give up my clinical activities.

d) ( ) I would give up carrying out my didactic and clinical activities.

10. In case you found out you were infected by HIV, would you tell your patients about it?

( ) Yes, I would.

( ) No, I would not.

If your answer is negative, why? (it is possible to check more than one answer)

a) ( ) worried about prejudice from patients.

b) ( ) worried about prejudice from workmates and students.

c) ( ) worried about possibility of losing clients.

d) ( ) another reason 